Boise State University

ScholarWorks

6-1-2016

\title{
Mid- and Long-Term Effects of Wildfire and Debris Flows on Stream Ecosystem Metabolism
}

Quenton M. Tuckett

Boise State University

Peter Koetsier

Boise State University 


\title{
Mid- and long-term effects of wildfire and debris flows on stream ecosystem metabolism
}

\author{
Quenton M. Tuckett ${ }^{1,2}$ and Peter Koetsier ${ }^{1,3}$ \\ ${ }^{1}$ Boise State University, Department of Biology, 1910 University Drive, Boise, Idaho 83725 USA
}

\begin{abstract}
Wildfire is an important and prevalent agent of disturbance in vegetated landscapes across much of the Earth's surface, including forested watersheds in the arid western USA. Between 1992 and 2003, >40\% of the watersheds in the upper reaches of the Boise River watershed in central Idaho burned. The purpose of our study was to investigate the legacy effects of wildfire on stream ecosystems by analyzing the relationship between wildfire and resulting debris flows and their joint effects on stream ecosystem metabolism in 31 streams. The watersheds of $\sim 1 / 2$ of these streams burned within the last $11 \mathrm{y}$, and some of these burned watersheds also experienced large-scale debris flows 1 y postfire. Streams with burned watersheds recovered quickly, and estimates of photosynthetically active radiation, gross primary production, and ecosystem respiration were indistinguishable from those in streams draining unburned watersheds. However, streams that experienced debris flows after their watersheds burned were remarkably different. They exhibited higher production and incident light and lower ecosystem respiration. Debris flows resulted in nearly complete removal of streamside vegetation, slowed recovery of the riparian canopy, and altered stream ecosystem metabolism. Our results suggest a synergistic interaction between wildfire and associated geomorphological processes whereby debris flows delay succession of stream ecosystems, possibly resulting in altered recovery trajectories, communities, and foodweb interactions.

Key words: streams, wildfire, debris flows, ecosystem metabolism, gross primary production
\end{abstract}

Disturbance shapes stream ecosystem processes (Resh et al. 1988, Reice 1994), suggesting that streams are always recovering from the last disturbance (Reice 1994). In North America and elsewhere, wildfire is a common, large-scale, natural disturbance that influences ecosystem function, organismal diversity, and the heterogeneity of stream ecosystems (Resh et al. 1988, Minshall et al. 1989, 1997, Verkaik et al. 2013). The effects of wildfire on stream ecosystems have been characterized in terms of the mechanism of impact (direct or indirect) and temporal scale of influence (short-, mid- and long-term) (Minshall et al. 1997, Gresswell 1999). Studies often take place immediately after wildfire (short-term: $<1$ y) or relatively shortly thereafter (midterm: $\sim 1-10 \mathrm{y}$ ), and investigators often examine direct (altered resources, temperature, vegetation) and indirect (geological processes) effects, often in relation to stream biota (Mihuc and Minshall 1995, Minshall et al. 1997, Verkaik et al. 2013). Interest in the potential interaction of direct and indirect agents, including the incidence of largescale debris flows in streams, is growing (Dunham et al. 2007, Lyon and O'Connor 2008, Rosenberger et al. 2011). However, little is known about effects of wildfire that extend beyond a decade (long-term: $>10-300$ y), especially regarding ecosystem responses such as changes in stream metabolism, and how recovery might interact with debris flows.

In 1994, the Star Gulch and Rabbit Creek Wildfires (collectively called the Idaho City Complex) burned $\sim 74,000$ ha in central Idaho. A year later, intense summer thunderstorms caused large slope failures, gullying, and rill erosion in the Boise River watershed and culminated in large-scale debris flows (Burton 2005, Dunham et al. 2007). A similar scenario occurred after the 2003 Hot Creek Fire (Rosenberger et al. 2012). Sporadic channel reorganization and debris flows can be associated with wildfire in this area because of the regional lithology (Meyer et al. 2001, Burton 2005). However, on broader time scales, such as centuries or millennia, debris flows are a regular part of the disturbance regime (Meyer and Pierce 2003, Pierce et al. 2004). The occurrence of debris flows is generally related to the local topography and climate and specifically related to the timing of precipitation in the watershed. Precipitation interacts synergistically with fire severity to alter soil organic matter and cohesion, the vegetative canopy, and ground cover (Moody and Martin 2001, Parise and Cannon 2012). Debris flows can affect stream ecosystems because flows

E-mail addresses: ${ }^{2}$ Present address: University of Florida/IFAS, SFRC Program in Fisheries and Aquatic Sciences, Tropical Aquaculture Laboratory, $140824^{\text {th }}$ Street SE, Ruskin, Florida 33570 USA, qtuckett@ufl.edu; ${ }^{3}$ pkoet@boisestate.edu

DOI: 10.1086/686151. Received 11 June 2015; Accepted 18 November 2015; Published online 3 March 2016.

Freshwater Science. 2016. 35(2):445-456. ๑ 2016 by The Society for Freshwater Science. 
can cause extensive channel scouring and deposition, which can remove or bury riparian vegetation (Meyer et al. 2001, Dwire and Kauffman 2003), prolonging ecosystem recovery compared with that of a burned but unscoured stream (Lamberti et al. 1991).

Altered recovery trajectories of streams in burned watersheds, especially those experiencing debris flows, may be particularly evident for ecosystem responses, such as stream metabolism, because this measure can be sensitive to disturbance (Young and Huryn 1999, Sweeney et al. 2004), especially floods (Fisher et al. 1982, Uehlinger 2000, Uehlinger et al. 2003). Wildfire can affect metabolism directly by removing riparian vegetation and associated allochthonous subsidies and indirectly by increasing incident light, water temperatures, and woody debris inputs (Minshall et al. 1997, Robinson et al. 2005, Isaak et al. 2010). Substrate mobility, sedimentation, and nutrient concentrations also may be affected (Minshall et al. 1997, Spencer et al. 2003). Increased temperature and light and reduced litter inputs should shift the relative importance of the allochthonous and autochthonous energy pathways, moving burned streams away from heterotrophic expectations. Minshall et al. (1989) suggested that gross primary production (GPP) would peak in the $1^{\text {st }}$ postfire year when canopy cover is sparse and nutrient concentrations are elevated. GPP would then return to prefire levels in 2 to $6 \mathrm{y}$ after canopy recovery. The response of ecosystem respiration (ER) to wildfire and associated scouring is less understood. Ultimately, the long-term response of GPP and ER to wildfire may be linked to the severity of the burn, the incidence of debris flows, and the degree of riparian canopy recovery.

The extensive and well-documented wildfire history of central Idaho provides an opportunity to apply a "spacefor-time" study design to examine the relationship between time since burn and the presence of debris flows and their joint effect on stream ecosystem metabolism. We studied 31 streams (16 in unburned and 15 in burned watersheds, some of which experienced debris flows) to address 2 questions. First, what are the persistent mid- and long-term effects of watershed wildfire and debris flows on stream ecosystem metabolism? Second, do streams in burned watersheds with debris flows represent a unique condition and exhibit an altered recovery trajectory? We estimated stream ecosystem metabolism with single-station, open-system methods and calculated reaeration constants ( $k$ ) based on the energy dissipation model (Odum 1957, Tsivoglou and Neal 1976, Bott 2007). We also measured stream variables with a documented influence on metabolism.

\section{METHODS}

\section{Site descriptions and burn history}

The lithology of the Boise National Forest in central Idaho is dominated by granites, which produce coarse soils that are highly erodible, lack cohesion, and exhibit low productivity after weathering (Meyer et al. 2001). The regional climate is continental and characterized by dry summers with frequent thunderstorms, which can contribute to routine floods and severe debris flows after wildfire (Meyer et al. 2001). We were unable to determine when flooding occurred at each stream, a potential limitation of this study. Average annual precipitation is $>45 \mathrm{~cm}$ at lower elevations and $125 \mathrm{~cm}$ above $2100 \mathrm{~m}$ asl. Variation in precipitation creates a forest-cover mosaic in which low-elevation forests are dominated by ponderosa pine (Pinus ponderosa) and higher-elevation forests by Douglas fir (Pseudotsuga menziesii). Forests in riparian areas are dominated by black cottonwoods (Populus trichocarpa) at low elevations and broad valleys and willow (Salix spp.) and water birch (Betula occidentalis) at headwater streams.

We used ArcGIS (version 9.1; Environmental Research Systems, Redlands, California) and assistance from US Department of Agriculture Forest Service personnel to select sites with maximum similarity based on fire perimeter, fire intensity, channel slope, and stream order. We chose 31 streams: 16 in unburned watersheds and 15 in watersheds that burned between 1992 and 2003 (Fig. 1). Streams in burned watersheds were further classified based on the incidence of debris flows (6 of 15 streams) and the time since fire. Our study has limited replication of some stream conditions and an unbalanced design because of the differential availability of streams in each burn category.

The fire history in the region allowed us to set up a space-for-time experiment with 5 stream conditions: 1) watersheds burned in 1994 (B94; $n=6), 2$ ) watersheds burned in 2000 (B00; $n=3$ ), 3) watersheds burned in 1992 and 1994 with associated debris flows 1 to 2 y postfire (S94, $n=3)$, 4) watersheds burned in 2003 with associated debris flows in 2004 and 2005 (S03, $n=3$ ), and 5) watersheds that were free or relatively free of disturbance by wildfire within the last century (UB, $n=16$ ) (Table S1, S2). Watersheds of B94 streams were burned in 1994 by the Idaho City Complex fires, and 2 of these streams (Trapper and Wren) experienced debris flows in 1995 and 1996 (Dunham et al. 2007, Rosenberger et al. 2011). The watershed of Sheep Creek was burned in the 1992 Foothills Fire, a 104,000-ha mixed-severity crown fire. Debris flows occurred on Sheep Creek in 1994. Data from Sheep Creek were analyzed with data from streams that experienced debris flows in 1995 and 1996 (Dunham et al. 2007, Rosenberger et al. 2011). Three streams were burned by the 13,000-ha Trail Creek Fire of 2000. Three streams in watersheds burned by the 10,700-ha Hot Creek Fire in 2003 all experienced debris flows, first in August 2003, then in June and August 2004, and before sampling in 2005. Streams were situated at elevations ranging from 1046 to $1856 \mathrm{~m}$ asl (mean $=1475 \pm 35 \mathrm{~m}$; Table S2). Stream gradients varied from 1.3 to $19.7 \%$ (mean $=5.0 \%$; Table $\mathrm{S} 2$ ). 


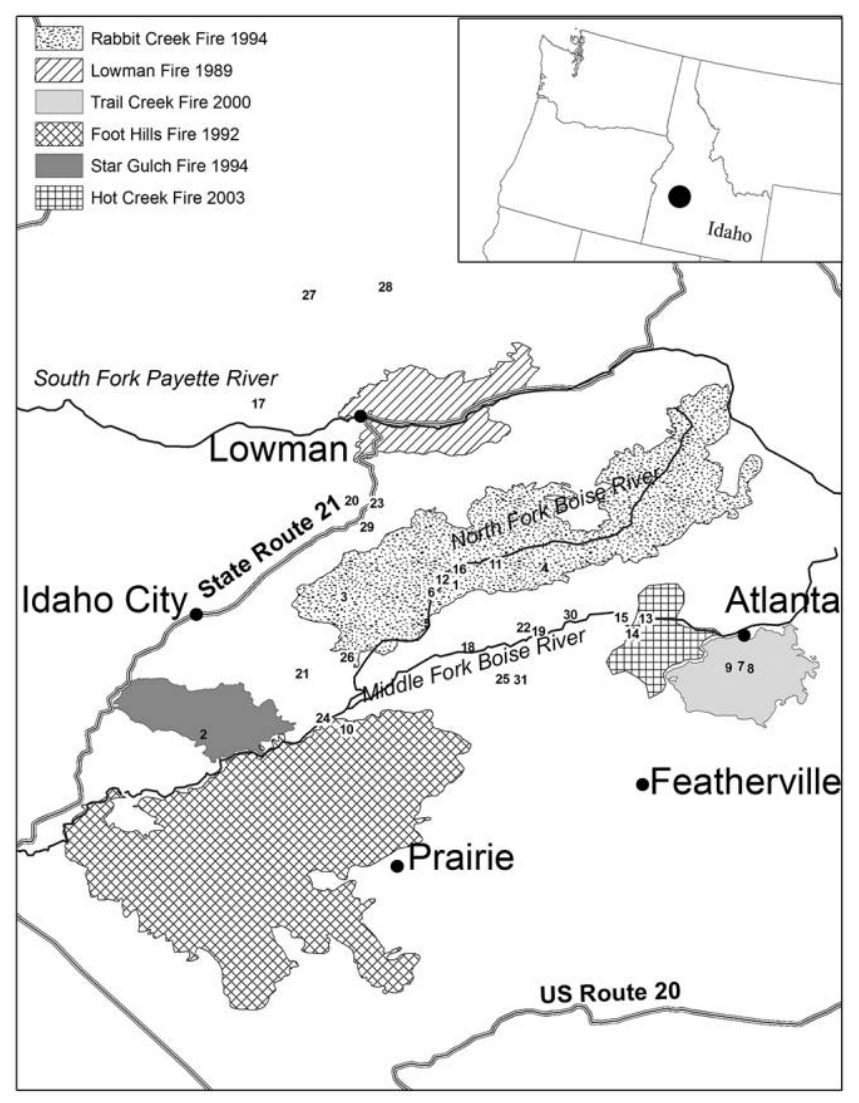

Figure 1. Locations of 31 study streams in the Boise and Payette River watersheds of central Idaho in relation to wildfire occurrence in this region since 1992. See Tables S1, S2 for stream coordinates and characteristics.

Elevation $\left(F_{4,26}=2.63, p=0.057\right)$ and slope $\left(F_{4,26}=2.61\right.$, $p=0.058)$ were similar among stream groups.

We sampled all 31 streams between 14 July and $21 \mathrm{Au}-$ gust. No rainfall was recorded on or before the day a sampling event took place. Where possible, our stream reaches were chosen to maximize reach homogeneity. To avoid the influence of forest roads, all sampling took place $\geq 250 \mathrm{~m}$ upstream of road crossings. We measured $\mathrm{pH}$ and specific conductance in situ with a handheld meter (YSI 63, Yellow Springs Instruments, Yellow Springs, Ohio). We collected water samples, stored them on ice, and transported them within $24 \mathrm{~h}$ to the laboratory where we measured alkalinity by titration according to standard methods (APHA 2005). We measured stream width at 10 random transects along a $100-\mathrm{m}$ study section. On each transect, we measured depth at 5 equidistant points and substratum size at 10 equidistant points (Wolman 1954, Bain 1999). At 50 of the 100 points, we visually estimated substrate embeddedness and \% cover of sand and silt. We counted pieces of large woody debris (LWD) $>2 \mathrm{~m}$ long and $15 \mathrm{~cm}$ diameter in the study section and standardized counts to the area of the study section (number $/ \mathrm{m}^{2}$ ). We measured incident light (photosynthetically active radiation $[\mathrm{PAR}]$ ) at 50 random points at the water surface on cloudless days between 1200 and $1400 \mathrm{~h}$ (LI-192SA underwater quantum sensor; LiCor, Lincoln, Nebraska).

\section{Stream metabolism}

We estimated whole-stream gross primary production (GPP) and ecosystem respiration (ER) with open-system, single-station diel $\mathrm{O}_{2}$ methods (Odum 1957, Bott 2007) on sunny days with no storms on or before the sampling day. We situated data loggers in a well-mixed position of the thalweg away from woody debris or boulders to measure DO (DO:1050; RBR Global, Kanata, Ontario) and water temperature (model H08-001-02; Onset, Cape Cod, Massachusetts) every $30 \mathrm{~min}$ for $24 \mathrm{~h}$. The DO logger was factory calibrated and recalibrated routinely in water saturated and unsaturated with DO and corrected for barometric pressure. The start of the recording followed a 1-h equilibration period.

Many methods, including the injection of an inert volatile gas such as propane or sulfur hexafluoride (Young and Huryn 1999, Bott 2007), are available for estimating reaeration ( $k$; gas exchange over air-water interface). However, we worked in remote, hazardous, burned watersheds. Therefore, we chose to use the energy dissipation model, which is based on DO, channel slope, current velocity, discharge, and mean depth (Elmore and West 1961, Tsivoglou and Neal 1976). The energy dissipation model is still widely used (e.g., Bellmore and Baxter 2014) and has advantages in that it does not require specialized equipment or transportation of gases to field sites.

We calculated the $\mathrm{O}_{2}$ reaeration rate $\left(\mathrm{kO}_{2}\right)$ as described by Tsivoglou and Neal (1976). We used 7.5' topographic maps in the software package Terrain Navigator Pro (version 7; MyTopo, Billings, Montana) to estimate channel slope. We measured current velocity $(\mathrm{m} / \mathrm{s})$ by taking $\sim 20$ measurements with a current meter (Model 2100; Swoffer Instruments, Seattle, Washington) at $60 \%$ depth. We estimated discharge from 10 velocity-depth profiles made with a current meter at 60\% depth (Gallagher and Stevenson 1999). More profiles were taken when streams were wider or bed roughness was greater. We modified the gasexchange coefficient at $20^{\circ} \mathrm{C}\left(K_{2\left(20^{\circ}\right)} / \mathrm{d}\right)$ at each 30-min sampling interval to reflect gas exchange at the measured water temperature (Elmore and West 1961).

We calculated in situ metabolism estimates by solving the Velz model (Bott 2007). For each 30-min time interval, we estimated $\% \mathrm{O}_{2}$ saturation based on site elevation, DO, and temperature. We modified $\% \mathrm{O}_{2}$ saturation based on $k$. We corrected DO rates of change between adjacent time intervals for gas exchange by averaging adjacent gasexchange values and adding the gas-exchange values to the DO rate of change. We graphed corrected DO rates 
of change over time. Positive values above the 0 rate-ofchange line (ER) indicated production and negative values indicated respiration. ER was calculated by extrapolating hourly respiration rates to $24 \mathrm{~h}$, assuming roughly equal daytime and nighttime respiration rates. We calculated day length from times of sunset and sunrise in the Idaho City area (National Weather Service; www.weather.gov) and estimated GPP based on the assumption that daytime and nighttime respiration rates were roughly equal (Bott 2007). We calculated areal estimates of production by multiplying GPP and ER by mean stream width. We calculated net daily metabolism (NDM $=$ GPP - ER) and the production to respiration ratio $(\mathrm{P}: \mathrm{R}=\mathrm{GPP} / \mathrm{ER})$. We estimated metabolic rates over a short period $(24 \mathrm{~h})$ with a single daily sample at each of the 31 streams. Thus, our results represent a snapshot of long-term trends.
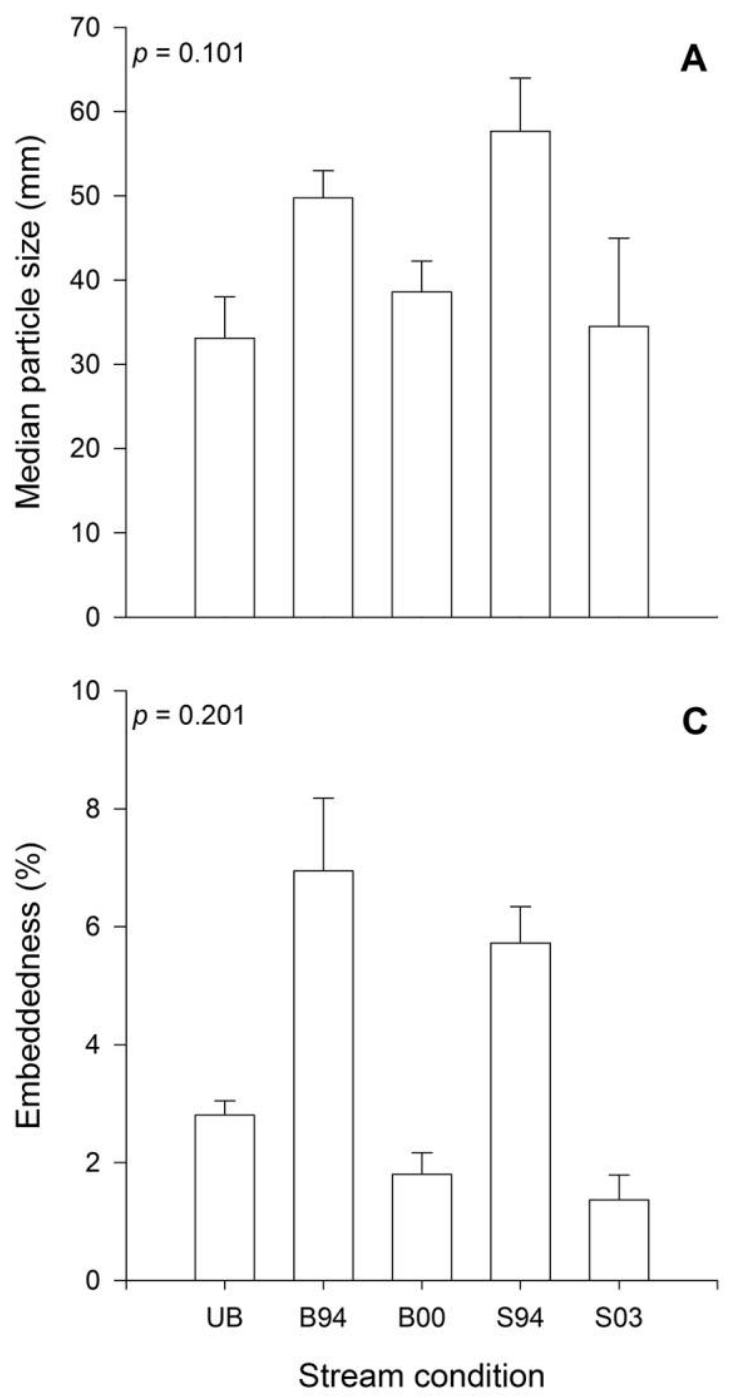

\section{Data analysis}

We assessed normality of all variables with ShapiroWilk goodness-of-fit tests and $\log _{10}(x)$ - or $\arcsin (x)$ - (for percentages) transformed variables if needed. We used 1way, nested analysis of variance (ANOVA) with stream reach as a random effect nested within stream condition (B94, B00, S94, S03, UB) to examine among-stream-condition differences in habitat variables and metabolic rates. When the ANOVA indicated a stream-condition effect, we used a priori Student's $t$ tests to identify which means differed. When we found among-stream-condition differences in stream habitat variables, we applied linear regression to GPP for each of these variables.

We used a multiple analysis of variance (MANOVA) followed by canonical discriminant analysis (CDA) to identify the variables that best discriminated among stream condi-
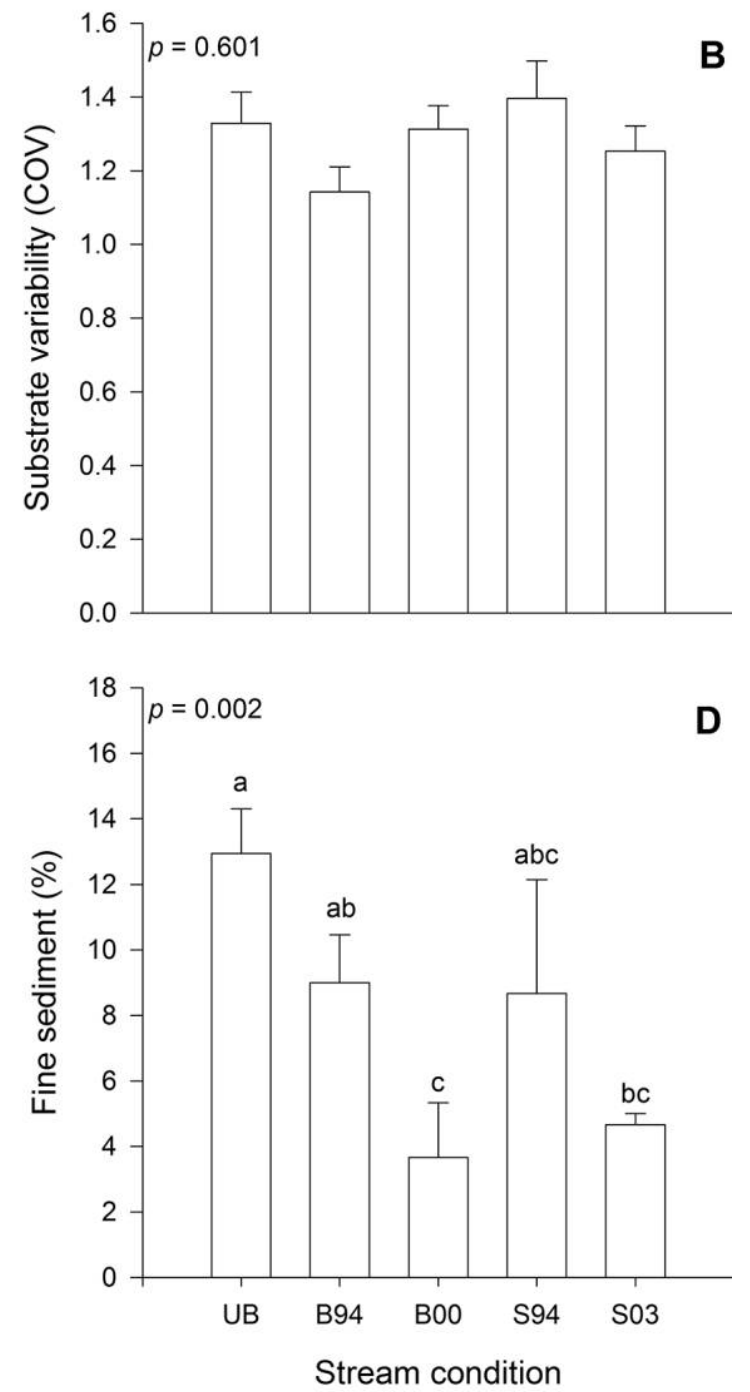

Figure 2. Median (+1 SE) particle size (A), substrate variability expressed as coefficient of variation (COV) (B), substrate embeddedness (C), and \% fine sediment (D) by stream condition. Stream conditions are unburned (UB; $n=16$ ), burned in 1994 (B94; $n=6$ ), burned in 2000 (B00; $n=3$ ), burned in 1992 or 1994 and subsequently scoured (S94; $n=3$ ), and burned in 2003 and subsequently scoured $(\mathrm{S} 03 ; n=3)$. Bars with the same letters are not significantly different $(p>0.05)$. 
tions (McGarigal et al. 2000). We transformed all variables to $z$-scores (mean $=0$, standard deviation $=1$ ) and used stepwise forward selection to identify transformed habitat and metabolism variables that best separated stream conditions. We selected 11 of the 24 habitat and metabolism variables for inclusion in the model.

We ran regressions and nested and simple ANOVAs with JMP statistical software (version 5.1; SAS Institute, Cary, North Carolina) and CDA with SAS statistical software (version 9.1; SAS Institute).

\section{RESULTS}

\section{Stream conditions}

Alkalinity varied from $22 \mathrm{mg} \mathrm{CaCO}_{3} / \mathrm{L}$ at Lost Man and No Man Creeks to $106 \mathrm{mg} \mathrm{CaCO}_{3} / \mathrm{L}$ at Beaver Creek, and averaged $51 \pm 3.3(\mathrm{SE}) \mathrm{mg} \mathrm{CaCO}_{3} / \mathrm{L}$ (Table S2). Me- dian particle size $\left(F_{4,26}=2.2, p=0.101\right.$; Fig. $\left.2 \mathrm{~A}\right)$, substrate coefficient of variation $\left(F_{4,26}=0.7, p=0.601\right.$; Fig. $\left.2 \mathrm{~B}\right)$, embeddedness $\left(F_{4,26}=1.6, p=0.201\right.$; Fig. $\left.2 C\right)$, and large woody debris $\left(\mathrm{F}_{4,26}=2.0, \mathrm{p}=0.1307\right)$ were similar among stream conditions. Fine sediments varied from $2 \%$ at Sawmill and Grouse Creeks (B00) to 23\% at Noman Creek $(\mathrm{UB})$ and differed among stream conditions $\left(F_{4,26}=5.8\right.$, $p=0.002$; Fig. 2D). Percent fine sediment was higher at UB streams than at S03 and B00 streams.

Mean PAR was lower at UB than at all other stream conditions and higher at S03 streams than at B94 streams $\left(F_{4,26}=11.6, p<0.001\right.$; Fig. 3A). S94 streams had the highest 24-h mean water temperatures, whereas UB and B00 had the lowest $\left(F_{4,26}=6.6, p<0.001\right.$; Fig. 3B). Maximum water temperature differed among stream conditions $\left(F_{4,26}=15.3, p<0.001\right.$; Fig. 3C), and 4 of 6 S94 and S03 streams had maximum temperatures $>20^{\circ} \mathrm{C}$. In particular,
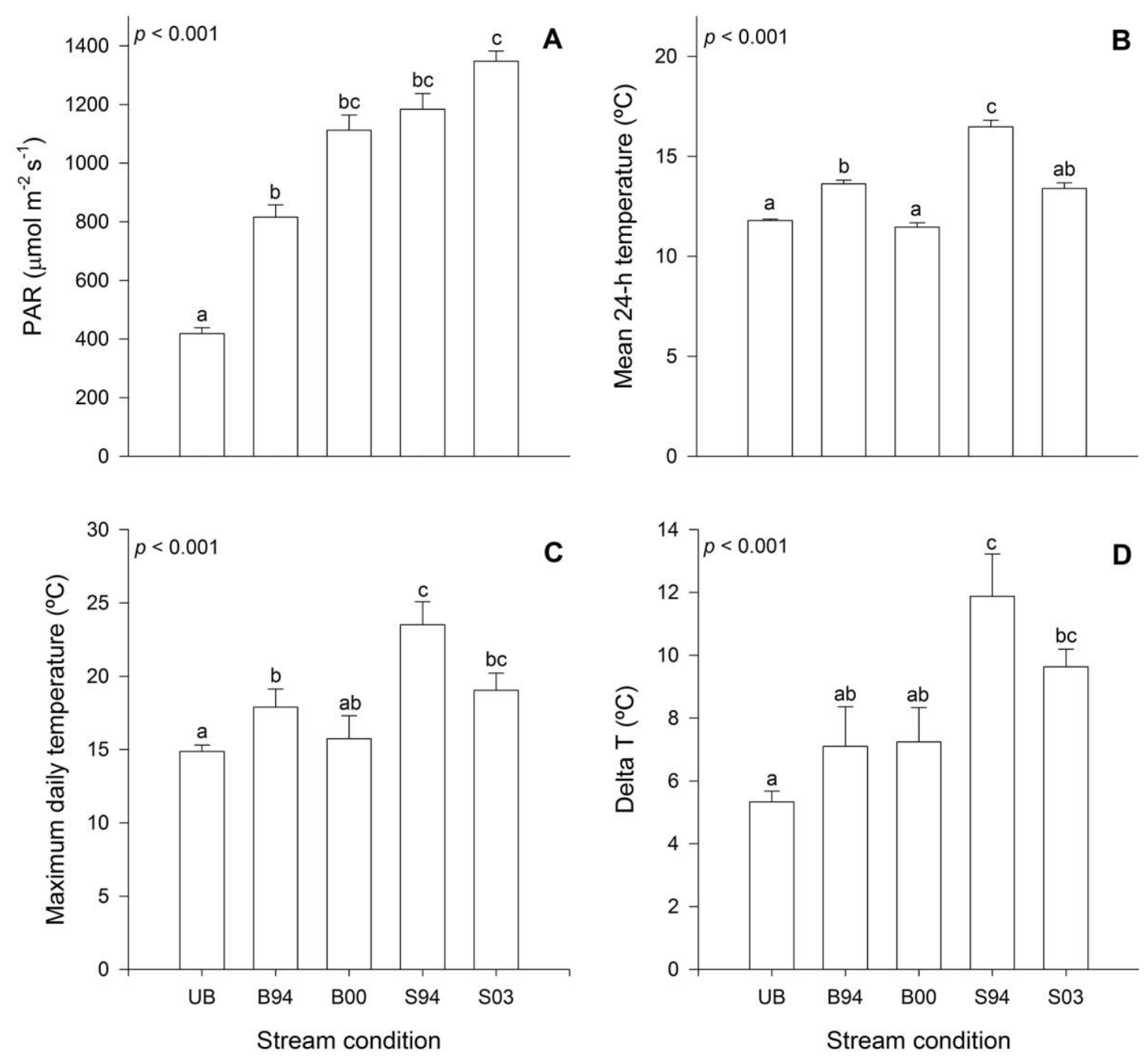

Figure 3. Mean (+1 SE) photosynthetically active radiation (PAR) (A), mean 24-h temperature (B), maximum daily temperature (C), and temperature fluctuation (delta T) (D) by stream condition. See Fig. 2 for an explanation of stream conditions. Bars with the same letters are not significantly different $(p>0.05)$. 
Wren Creek had a maximum temperature $>26^{\circ} \mathrm{C}$. Daily temperature fluctuations (delta $\mathrm{T}$ ) varied among stream conditions $\left(F_{4,26}=6.6, p<0.001\right.$; Fig. $\left.3 \mathrm{D}\right)$. S94 streams had the largest delta $\mathrm{T}\left(11.9^{\circ} \mathrm{C}\right)$; B94, B00, and $\mathrm{S} 03$ streams were intermediate, and $\mathrm{UB}$ streams had the smallest delta $\mathrm{T}\left(5.3^{\circ} \mathrm{C}\right)$. Daily temperature and PAR were positively related $\left(F_{1,29}=\right.$ 5.4, $\left.r^{2}=0.16, p=0.028\right)$.

\section{Stream ecosystem metabolism}

$K_{2\left(20^{\circ}\right)} / \mathrm{d}$ varied from 8.1 to 183.6 and differed among stream conditions $\left(F_{4,26}=6.2, p=0.001\right.$; Table S3). Reaeration was highest for B00 $(62.3 \pm 7.8)$ and S03 (60.8 \pm 11.1) streams and lowest for S94 (33.9 \pm 9.1), B94 (29.1 \pm $6.4)$, and UB $(24.9 \pm 3.9)$ streams. Metabolism was highly variable in the 31 stream reaches, and GPP ranged from $0.3 \mathrm{~g} \mathrm{O}_{2} \mathrm{~m}^{-2} \mathrm{~d}^{-1}$ (Browns Creek; UB) to $4.4 \mathrm{~g} \mathrm{O}_{2} \mathrm{~m}^{-2} \mathrm{~d}^{-1}$ (Wren Creek; S94). GPP was higher at S03 streams than at all other stream conditions and higher at S94 than at UB, B94, and B00 streams $\left(F_{4,26}=14.5, p=0.001\right.$; Fig. $\left.4 \mathrm{~A}\right)$. A temporal sequence of recovery was apparent. B00 streams tended to have higher GPP than B94 streams, but only S94 and S03 had greater GPP than UB streams. GPP increased with PAR $\left(F_{1,29}=10.3, r^{2}=0.25, p=0.003\right)$ and mean temperature $\left(F_{1,29}=9.2, r^{2}=0.24, p=0.005\right)$ but decreased with \% fine sediment $\left(F_{1,29}=6.2, r^{2}=0.17, p=\right.$ 0.020). ER ranged more than GPP $\left(0.6 \mathrm{~g} \mathrm{O}_{2} \mathrm{~m}^{-2} \mathrm{~d}^{-1}\right.$ at Buck Creek [UB] to $7.4 \mathrm{~g} \mathrm{O}_{2} \mathrm{~m}^{-2} \mathrm{~d}^{-1}$ at Hungarian Creek [B94]; Table S3) but was similar among stream conditions $\left(F_{4,26}=2.1, p=0.101\right.$; Fig. $\left.4 \mathrm{~B}\right)$. ER was unrelated to GPP $\left(F_{1,29}=0.006, p=0.940\right)$.

NDM varied from $-6.5 \mathrm{~g} \mathrm{O}_{2} \mathrm{~m}^{-2} \mathrm{~d}^{-1}$ (Hungarian Creek; B94) to $3.1 \mathrm{~g} \mathrm{O}_{2} \mathrm{~m}^{-2} \mathrm{~d}^{-1}$ (Wren Creek; S94) (Table S3) and differed among stream conditions $\left(F_{4,26}=\right.$ 4.4, $p=0.008$; Fig. 4C). S94 and S03 streams were net exporters of energy and had greater NDM than UB, B94, or B00 streams, which did not differ. Seven of 31 streams, including all 6 S94 and S03 streams, had P:R >1 (Fig. 5A). S94 and S03 streams had significantly higher P:R than UB, B94, or B00 streams, which did not differ $\left(F_{4,26}=33.6\right.$, $p<0.001$; Fig. 5B).

\section{CDA}

CDA revealed strong differences between S94 and S03 streams and UB, B94, and B00 streams (Wilks' $\lambda, F_{44,63}=$ $4.4, p<0.001$; Fig. 6). Three canonical axes explained $96 \%$ of the group variation. Canonical axis 1 (CA1) explained $\sim 47 \%$ of the variation $\left(F_{40,66}=3.9, p<0.001\right)$, CA2 explained $\sim 37 \%\left(F_{27,53}=3.1, p<0.001\right)$, and CA3 explained $\sim 13 \%\left(F_{16,38}=1.9, p=0.048\right)$ (Table 1$)$. CA1 discriminated between S03 streams and all other stream conditions. Temperature and metabolism estimates, especially GPP, loaded heavily on this axis (Table 1, Fig. 6). CA2 separated S94 and all other stream conditions. GPP, P:R, ER, and delta T loaded heavily on CA2, and GPP had the lowest scoring
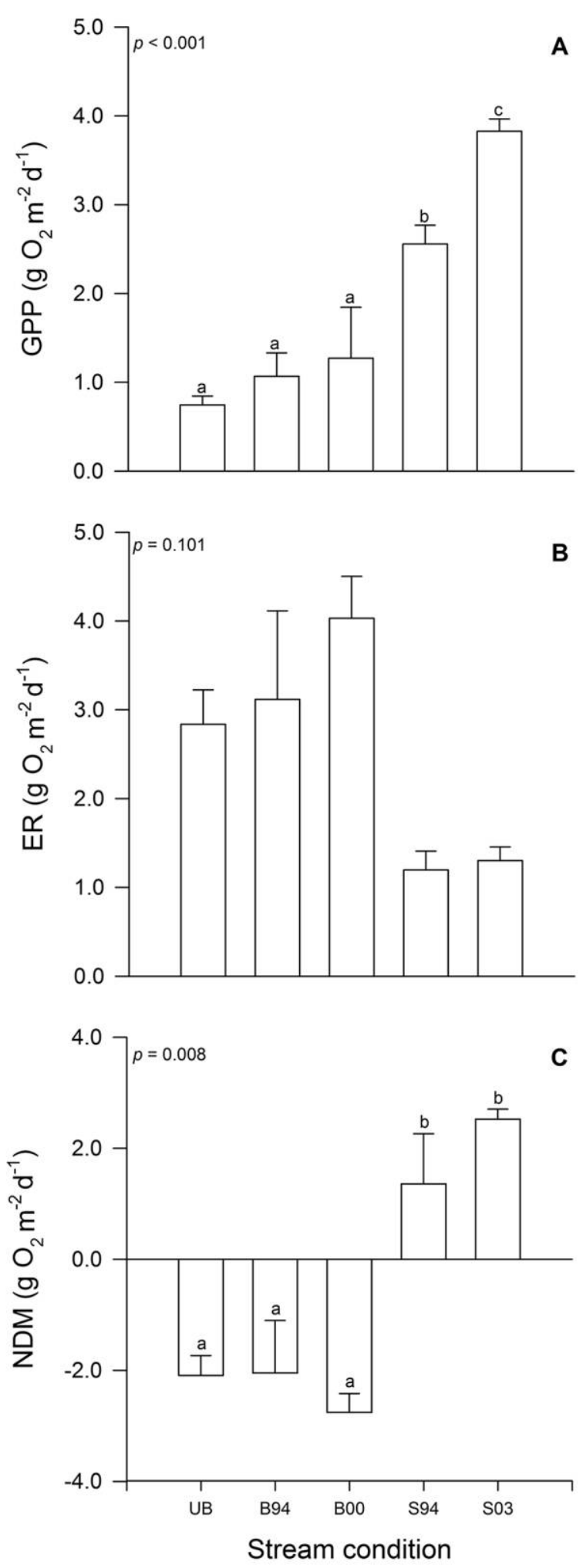

Figure 4. Mean (+1 SE) gross primary production (GPP) (A), ecosystem respiration (ER) (B), and net daily metabolism (NDM) (C) by stream condition. See Fig. 2 for an explanation of stream conditions. Bars with the same letters are not significantly different $(p>0.05)$. 

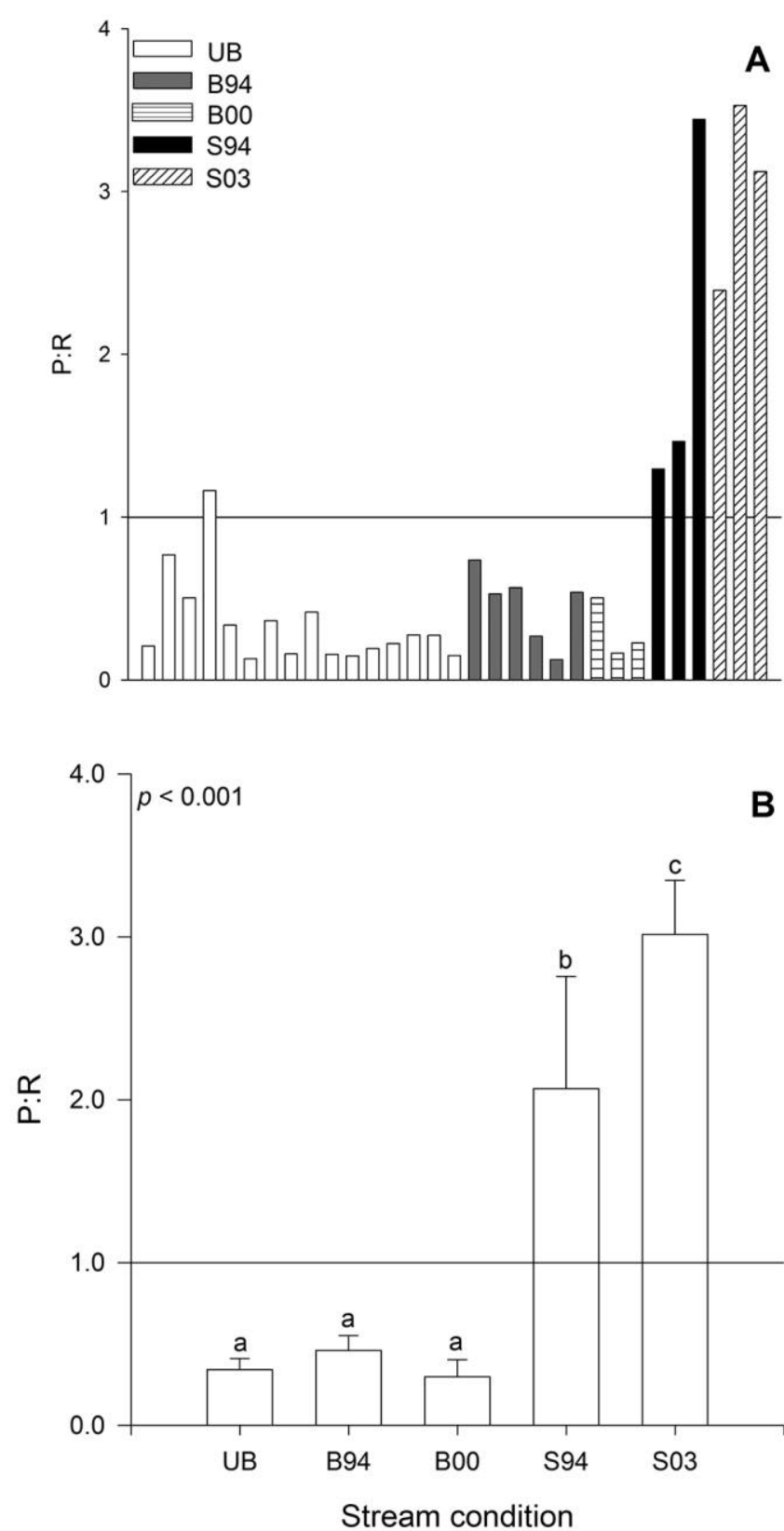

Figure 5. Mean $(+\mathrm{SE})$ production to respiration ratios $(\mathrm{P}: \mathrm{R})$ for all 31 streams (A) and by stream condition (B). See Fig. 2 for an explanation of stream conditions. Bars with the same letters are not significantly different $(p>0.05)$.

coefficient. Maximum temperature, delta T, P:R, and PAR loaded heavily on CA3. Metabolism and temperature variables exhibited the greatest ability to discriminate among stream conditions (Table 1).

\section{DISCUSSION}

Overall, our results suggest that ecosystem indicators (e.g., GPP, P:R) can return quickly to prefire levels as vegetation recovers. This result is consistent with predictions for mid-term recovery of metabolic indicators to prefire levels (Minshall et al. 1989). The recovery trajectory and the eventual return to heterotrophy can be altered by the incidence of debris flows, which bury or remove riparian vegetation and delay the ultimate return of the canopy. Given expectations for a warming climate and associated increases in wildfire (Westerling et al. 2006), the conditions described here may become a more regular occurrence. A modified thermal regime and greater reliance on in-stream production has implications for the trophic structure of streams and could present challenges to native coldwater biota (Isaak et al. 2010).

We showed that wildfire and associated debris flows result in increased heterogeneity of ecosystem functioning resulting from synergistic interactions between wildfire and the parent lithology, such that streams which experience postfire debris flows are quite different with altered recovery trajectories. Some physical variables, especially stream substrate, were poorer predictors of watershed fire than were metabolism variables. Our metabolic variables provided a simple snapshot of ecosystem functioning, but our results suggest that GPP, ER, and P:R may integrate the dominant postfire changes in stream ecosystems.

\section{Stream habitat}

Local watershed variables influence the postfire response of streams in burned watersheds, so the recovery process, pattern, and timing exhibited by these streams is unique (Minshall et al. 1997, 2001). Stream substrate (particle size,

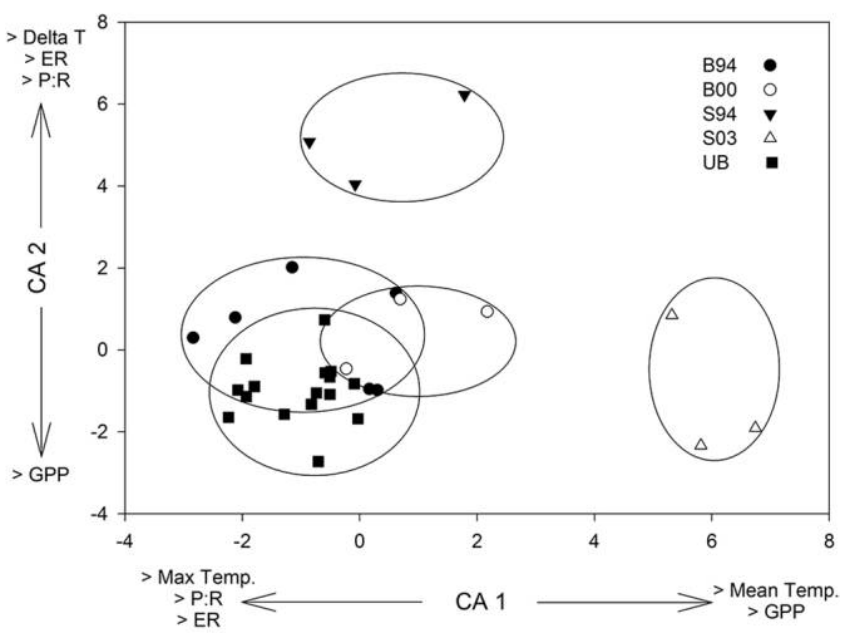

Figure 6. Canonical discriminant analysis plot of 31 streams coded by stream condition. Variables that characterize each axis (CA 1 and CA 2) are indicated. See Fig. 2 for an explanation of stream conditions. GPP $=$ gross primary production, $\mathrm{P}: \mathrm{R}=$ productivity:respiration, ER = ecosystem respiration, Delta $\mathrm{T}=$ temperature fluctuation, Mean temp. = mean 24-h daily temperature, Max temp. = maximum daily temperature. Ellipses enclose all symbols for each stream condition. 
Table 1. Canonical discriminant function coefficients for habitat variables with high loading for each canonical axis (CA). Variables were first subjected to stepwise forward selection. - indicates this variable was not selected for entry into the model and, therefore, no canonical discriminant function coefficient is reported. GPP = gross primary production, $\mathrm{P}: \mathrm{R}=$ productivity: respiration, $\mathrm{ER}=$ ecosystem respiration, $\mathrm{NDM}=$ net daily metabolism, PAR = photosynthetically active radiation, $\mathrm{SD}=$ standard deviation, $\mathrm{LWD}=$ large woody debris, $\mathrm{CV}=$ coefficient of variation.

\begin{tabular}{|c|c|c|c|}
\hline Variable & CA 1 & CA 2 & CA 3 \\
\hline $\operatorname{GPP}\left(\mathrm{g} \mathrm{O}_{2} \mathrm{~m}^{-2} \mathrm{~d}^{-1}\right)$ & 3.18 & -2.91 & -0.05 \\
\hline Maximum temperature $\left({ }^{\circ} \mathrm{C}\right)$ & -1.92 & -1.34 & 2.42 \\
\hline $\mathrm{P}: \mathrm{R}$ & -1.21 & 2.76 & -1.36 \\
\hline Mean temperature $\left({ }^{\circ} \mathrm{C}\right)$ & 1.19 & 1.14 & -0.47 \\
\hline $\mathrm{ER}\left(\mathrm{g} \mathrm{O}_{2} \mathrm{~m}^{-2} \mathrm{~d}^{-1}\right)$ & -1.07 & 1.41 & 0.47 \\
\hline $\operatorname{NDM}\left(\mathrm{g} \mathrm{O}_{2} \mathrm{~m}^{-2} \mathrm{~d}^{-1}\right)$ & -1.01 & 1.01 & 0.31 \\
\hline $\operatorname{PAR}\left(\mu \mathrm{mol} \mathrm{m}{ }^{-2} \mathrm{~s}^{-1}\right)$ & 0.81 & 0.09 & 0.99 \\
\hline Median particle size $(\mathrm{mm})$ & -0.59 & -0.15 & 0.21 \\
\hline SD particle size & 0.11 & 0.63 & -0.22 \\
\hline Delta $\mathrm{T}\left({ }^{\circ} \mathrm{C}\right)$ & -0.1 & 2.14 & -1.4 \\
\hline$\%$ fine sediment & -0.1 & -0.3 & -0.26 \\
\hline Alkalinity $(\mathrm{mg} \mathrm{CaCO} / \mathrm{L})$ & - & - & - \\
\hline Average water velocity $(\mathrm{m} / \mathrm{s})$ & - & - & - \\
\hline Conductivity $(\mu \mathrm{S} / \mathrm{cm})$ & - & - & - \\
\hline Depth $(\mathrm{m})$ & - & - & - \\
\hline Discharge $\left(\mathrm{m}^{3} / \mathrm{s}\right)$ & - & - & - \\
\hline Elevation (m) & - & - & - \\
\hline Embeddedness (\%) & - & - & - \\
\hline LWD (pieces/m²) & - & - & - \\
\hline Mean dissolved $\mathrm{O}_{2}(\mathrm{mg} / \mathrm{L})$ & - & - & - \\
\hline $\mathrm{pH}$ & - & - & - \\
\hline Slope (\%) & - & - & - \\
\hline Substrate CV & - & - & - \\
\hline Wetted width (m) & - & - & - \\
\hline Eigenvalues & 5 & 3.88 & 1.36 \\
\hline Variance explained (\%) & 47.03 & 36.49 & 12.8 \\
\hline
\end{tabular}

substrate variability, and embeddedness) was mostly unresponsive to fire and debris flows. However, we did note changes in \% fine sediment. Overall, streams in burned watersheds exhibited decreased fine sediment relative to streams in unburned watersheds and was lowest in the most recently burned watersheds (B00, S03). This result was unexpected. Burned watersheds typically lack the ground cover needed to protect against export of sediment from upland areas to the stream channel, so streams in burned watersheds typically have high \% fine sediment (Ice et al. 2004, Rulli and Rosso 2007). However, increased discharge in streams in burned watersheds can decrease short- and mid- term sediment retention (Lane et al. 2006). Thus, more sediment imported from upland areas may be offset by higher stream discharge and greater downstream sediment export. A reduction in fine sediment could lead to increased GPP because of greater substrate stability (Houser et al. 2005, Fellows et al. 2006, Atkinson et al. 2008).

Removal of riparian vegetation by wildfire increased the amount of sunlight (PAR) reaching the stream. As a result, streams in burned and scoured watersheds had higher water temperatures than did streams in unburned watersheds. PAR and water temperature are strongly related (Isaak et al. 2010), but other factors, including the location of the stream in the river basin, can affect stream temperature. For example, streams in watersheds that burned in 2000 were at elevations $>1800 \mathrm{~m}$ and, therefore, had lower water temperatures than lower-elevation streams in watersheds that burned in 1994. Overall, PAR was a better predictor than stream temperature of wildfire effects on metabolic variables and typically was greater at streams in recently burned or burned-and-scoured watersheds than at streams in unburned watersheds or burned-but-not-scoured watersheds that had been recovering since 1994. Furthermore, the effects of debris flow on PAR were persistent. PAR was similar in S94 and S03 streams.

PAR and stream canopy cover also are strongly related (Naiman et al. 1987, Lamberti and Steinman 1997). Based on our PAR measurements, little canopy recovery occurred at scoured streams during the $1^{\text {st }}$ postfire decade. Given appropriate conditions, the riparian canopy recovers quickly after fire because regrowth can occur from below-ground root structures that remain intact (Dwire and Kauffman 2003, Pettit and Naiman 2007). Recovery of the riparian canopy was readily observed at B94 streams (cf. Fig. 7A and $B$ ). These sites were difficult to access and sample because of the low, dense canopy composed mostly of species that exhibit rapid vegetative growth (e.g., cottonwoods and willows; Fig. 7B). Such species may be abundant after fire because of their ability to resprout (Pettit and Naiman 2007). However, postfire debris flows destroyed or buried much of the regenerative structures (above- and belowground) in burned and scoured watersheds, and S94 streams had little canopy recovery during the postfire decade (Fig. 7C). Thus, removal of above- and below-ground structures by debris flows can delay canopy recovery and increase stream temperature and PAR, which should alter stream ecosystem metabolism and the predicted successional trajectory.

\section{Stream metabolism}

GPP in our 31 study streams ranged from 0.3 to $4.4 \mathrm{~g}$ $\mathrm{O}_{2} \mathrm{~m}^{-2} \mathrm{~d}^{-1}$. This range of values is slightly broader and higher than in other studies based on similar methods in small North American streams (Fellows et al. 2001, Hall 

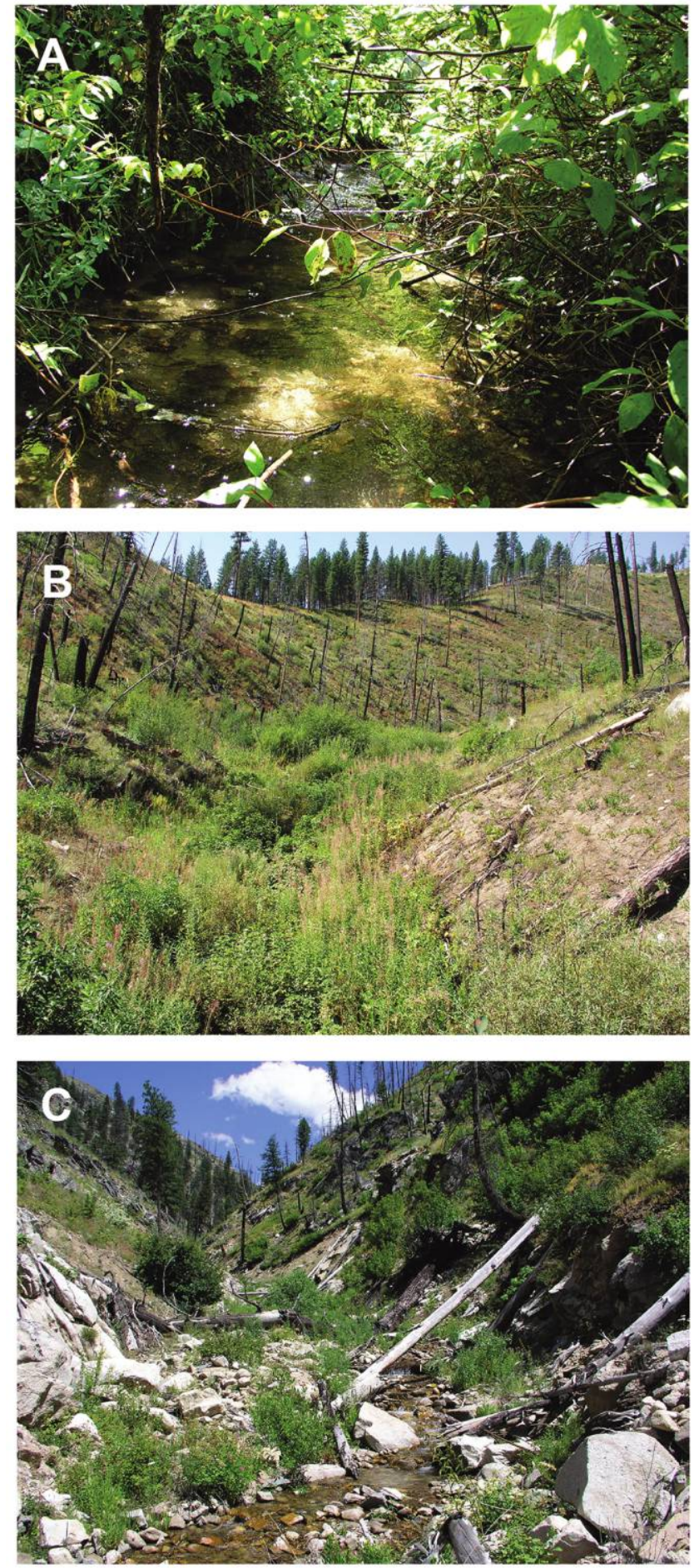

Figure 7. Photographs showing representative streams in watersheds that were unburned (Beaver Creek) (A), burned in 1994 (Lost Creek) (B), and burned in 1994 and subsequently scoured (Wren Creek) (C).

and Tank 2003, Houser et al. 2005). The broad range was expected given the spatial scale of our study, multiple stream disturbance histories, and the nearly complete ab- sence of canopy cover over scoured streams. Estimates of GPP found in our study streams indicate a temporal response to disturbance by wildfire and debris flows. GPP was highest at streams in recently burned watersheds and lowest at streams in unburned watersheds. This pattern has been implied several times in the literature (Minshall et al. 1989, 2001, Gresswell 1999) but has been verified rarely (but see Robinson et al. 2005). The temporal response we found was suggestive, but GPP at B94 and B00 streams was statistically indistinguishable from GPP at UB streams. This result indicates that GPP at streams in burned watersheds approaches prefire levels quickly and is consistent with predictions for mid-term (1-10 y) recovery and a strong relationship between GPP and canopy cover (Minshall et al. 1989). In contrast, GPP at streams in watersheds that burned in 1994 and experienced subsequent debris flows was still elevated at the time of our study (2005), indicating a unique recovery trajectory for systems affected by debris flows. Together, postfire changes to stream temperature, PAR, and fine sediment should alter GPP, and this expectation was consistent with our results. GPP was negatively related to $\%$ fine sediments and positively related to PAR and mean water temperature. Thus, GPP may be a good indicator of system recovery because it was responsive to the dominant postfire changes we identified.

In contrast, ER was inconsistent and ranged from 0.6 to $7.4 \mathrm{~g} \mathrm{O}_{2} \mathrm{~m}^{-2} \mathrm{~d}^{-1}$. Unlike other investigators (Robinson et al. 2005, Betts and Jones 2009), we did not find a postfire increase in ER. ER values in our study were lower than values reported by several others (Fellows et al. 2001, Mulholland et al. 2001, Houser et al. 2005). Acuña et al. (2004) reported a much broader range $\left(0.4-32.0 \mathrm{~g} \mathrm{O}_{2} \mathrm{~m}^{-2} \mathrm{~d}^{-1}\right)$ in just one Mediterranean stream. However, our ER rates are similar to those found in other studies in mountain streams (1.6-5.8 $\mathrm{g} \mathrm{O}_{2} \mathrm{~m}^{-2} \mathrm{~d}^{-1}$, Hall and Tank 2003; 1.4$8.3 \mathrm{~g} \mathrm{O}_{2} \mathrm{~m}^{-2} \mathrm{~d}^{-1}$, Bott et al. 2006). The narrow ER range in our 31 study streams may be influenced by the homogenous geology of the Boise River watershed, which is dominated by granites of the Idaho batholith, and by the particular disturbance history. Postfire debris flows scoured many of our streams extensively, often down to bedrock. The persistence and magnitude of scouring would reduce the size of the transient storage zone and ultimately limit ER (Mulholland et al. 2001).

GPP and ER in the study streams also could have been affected by more recent flooding (Fisher et al. 1982, Uelinger 2000, Uelinger et al. 2003) that could have led to the sometimes variable responses. We were unable to identify the date of the last flood disturbance because we worked in a region where the risk of flooding following thunderstorms was elevated by the loss of upland vegetation and concomitant increase in discharge and peak flow (Moody and Martin 2001, Shakesby and Doerr 2006). Ultimately, seasonal and long-term data are needed to fully understand 
the temporal sequence of recovery and how recovery interacts with debris flows and routine flooding.

Small, burned headwater streams that experienced debris flows were autotrophic, a condition that persisted for more than a decade postfire. The prevalence of autotrophy in scoured streams (S94 and S03) indicates that geological processes can severely alter stream ecosystems and delay recovery to the heterotrophic condition that predominates in temperate woodland streams and was the condition in 15 of the 16 UB streams (Cummins 1974, Vannote et al. 1980). The exception was Buck Creek, one of the widest streams in the study (wetted width $>3.5 \mathrm{~m}$ ). In contrast to the scoured streams, 24 of 25 burned (B94, B00) or UB streams were heterotrophic. As the summer progresses in temperate woodland systems, the riparian canopy becomes more dense, limiting light penetration to the stream, thereby decreasing GPP (Roberts et al. 2007). NDM mirrored the P:R because of how we calculated it.

Our results support the contention by Minshall (1978) that autotrophy can be an important energy source in streams. Even in streams thought to be heterotrophic, disturbance can alter the energetic contribution of autotrophs. Our study and others (e.g., Young and Huryn 1999) extend the view of autotrophy to include the dynamic nature of disturbance. Stream energy budgets are not static. Instead, they fluctuate seasonally over a backdrop of climate variability and the dominant disturbance regime (Young and Huryn 1999, Robinson et al. 2005, Roberts et al. 2007). Autotrophy in forested headwater streams may be more important than expected, especially in regions prone to wildfire and debris flows.

Our results suggest that variables related to stream ecosystem metabolism adequately discriminated among burn categories. Metabolic variables differed among stream conditions. These variables could be important tools in assessing stream functioning and health (Fellows et al. 2006), particularly in situations involving eutrophication or riparian clearing (Bunn et al. 1999, Houser et al. 2005). GPP may be particularly important because it appears to be sensitive to habitat-related impacts, such as canopy loss, sedimentation, and increased temperature.

\section{Conclusions}

Many studies including ours indicate that stream ecosystem metabolism has utility in identifying and quantifying disturbance (Bunn et al. 1999, Young and Huryn 1999, Houser et al. 2005, Fellows et al. 2006). Our study also suggests that stream ecosystem processes can recover quickly (few differences among UB, B94, and B00 streams), but that recovery is context dependent. Streams that were affected by debris flows exhibited nearly complete removal of riparian vegetation, with subsequent increases in temperature, PAR, and GPP that persisted $11 \mathrm{y}$ after a fire. Therefore, debris flows would indirectly affect biotic com- munity structure and availability/processing of basal C sources (Allan 2004, Koetsier et al. 2007, 2010). Furthermore, substrate disturbance associated with debris flows would alter community function by removing amphibians, fishes, macroinvertebrates, and diatoms and favoring r-strategist species that exhibit high dispersal rates, fast growth, and generalist feeding habits (Lyon and O'Connor 2008, Verkaik et al. 2013). Stream ecosystem recovery after wildfire may be delayed by a prolonged period of canopy return and substrate instability. In systems affected by debris flows, recovery will extend beyond the period predicted by Minshall et al. (1989) and will depend upon the time needed for vegetation to recover after a successional reset of the plant community, whereby woody riparian shrubs must sprout from seed and reach sufficient height and thickness to shade the stream, a process that could take 20 to $30 \mathrm{y}$, perhaps contributing to a landscape legacy (Foster et al. 1998).

Nearly $40 \%$ of the upper Boise River watershed has burned over the period from 1992 to 2003, resulting in higher-than-expected temperature and GPP throughout much of the Boise River watershed, a potential problem for the persistence of taxa including temperature-sensitive native fishes, such as trout and charr (Dunham et al. 2007, Isaak et al. 2010). Streams experiencing debris flows represent a unique ecological stream condition in this region and have much greater production and higher temperature over the long term than do streams in unburned or burned-but-not-scoured watersheds. Future studies should emphasize both temporal and spatial variation, which will give greater insight into the relationship between stream ecosystem metabolism and wildfire.

\section{ACKNOWLEDGEMENTS}

We thank the Boise Aquatic Sciences Laboratory of the US Department of Agriculture Forest Service, Rocky Mountain Research Station, and especially Jason Dunham, David Nagel, and Amanda Rosenberger. Project assistance was provided by Amber Fonner, Theresa Krause, Wilma Robertson, Cindy Valdivia, and Joshua White. Funding was provided by the US Department of Agriculture through a grant administered by the Cooperative State Research, Education, and Extension Service (CSREES). Additional funding was provided by Boise State University through the Dan Montgomery Grant for Ecological Research.

\section{LITERATURE CITED}

Acuña, V., A. Giorgi, I. Muñoz, U. Uehlinger, and S. Sabater, S. 2004. Flow extremes and benthic organic matter shape the metabolism of a headwater Mediterranean stream. Freshwater Biology 49:960-971.

Allan, J. D. 2004. Landscapes and riverscapes: the influence of land use on stream ecosystems. Annual Review of Ecology, Evolution, and Systematics 35:257-284.

APHA (American Public Health Association). 2005. Standard methods for the examination of water and wastewater. $20^{\text {th }}$ edi- 
tion. American Public Health Association, American Water Works Association, and Water Environment Federation, Washington, DC.

Atkinson, B. L., M. R. Grace, B. T. Hart, and K. E. N. Vanderkruk. 2008. Sediment instability affects the rate and location of primary production and respiration in a sand-bed stream. $\underline{\text { Jour- }}$ nal of the North American Benthological Society 27:581-592.

Bain, M. 1999. Substrate. Pages 95-100 in M. Bain and N. Stevenson (editors). Aquatic habitat assessment: common methods. American Fisheries Society, Bethesda, Maryland.

Bellmore, J. R., and C. V Baxter. 2014. Effects of geomorphic process domains on river ecosystems: a comparison of floodplain and confined valley segments. River Research and Applications 30:617-630.

Betts, E. F., and J. B. Jones. 2009. Impact of wildfire on stream nutrient chemistry and ecosystem metabolism in boreal forest catchments of interior Alaska. Arctic, Antarctic, and Alpine Research 41:407-417.

Bott, T. L. 2007. Primary productivity and community respiration. Pages 663-690 in F. R. Hauer and G. A. Lamberti (editors). Methods in stream ecology. $2^{\text {nd }}$ edition. Academic Press, San Diego, California.

Bott, T. L., J. D. Newbold, and D. B. Arscott. 2006. Ecosystem metabolism in piedmont streams: reach geomorphology modulates the influence of riparian vegetation. Ecosvstems 9:398-421.

Bunn, S. E., P. M. Davies, and T. D. Mosisch. 1999. Ecosystem measures of river health and their response to riparian and catchment degradation. Freshwater Biology 41:333-345.

Burton, T. A. 2005. Fish and stream habitat risks from uncharacteristic wildfire: observations from 17 years of fire-related disturbances on the Boise National Forest, Idaho. Forest Ecology and Management 211:140-149.

Cummins, W. 1974. Structure and function of stream ecosystems. BioScience 24:631-641.

Dunham, J. B., A. E. Rosenberger, C. H. Luce, and B. E. Rieman. 2007. Influences of wildfire and channel reorganization on spatial and temporal variation in stream temperature and the distribution of fish and amphibians. Ecosystems 10:335-346.

Dwire, K. A., and J. B. Kauffman. 2003. Fire and riparian ecosystems in landscapes of the western USA. Forest Ecology and Management 178:61-74.

Elmore, H., and W. West. 1961. Effects of water temperature on stream reaeration. Thirty-first progress report by Committee on Sanitary Engineering Division, American Society of Civil Engineers. Journal of the Sanitary Engineering Division 87:59-72.

Fellows, C. S., J. E. Clapcott, J. W. Udy, S. E. Bunn, B. D. Harch, M. J. Smith, and P. M. Davies. 2006. Benthic metabolism as an indicator of stream ecosystem health. Hydrobiologia 572: 71-87.

Fellows, C. S., H. M. Valett, and C. N. Dahm. 2001. Whole-stream metabolism in two montane streams: contribution of the hyporheic zone. Limnology and Oceanography 46:523-531.

Fisher, S. G., L. J. Gray, N. B. Grimm, and D. E. Busch. 1982. Temporal succession in a desert stream ecosystem following flash flooding. Ecological Monographs 52:93-110.

Foster, D. R., D. H. Knight, and J. F. Franklin. 1998. Landscape patterns and legacies resulting from large, infrequent forest disturbances. Ecosystems 1:497-510.
Gallagher, A., and N. Stevenson. 1999. Streamflow. Pages 149155 in M. Bain and N. Stevenson (editors). Aquatic habitat assessment: common methods. American Fisheries Society, Bethesda, Maryland.

Gresswell, R. E. 1999. Fire and aquatic ecosystems in forested biomes of North America. Transactions of the American Fisheries Society 128:193-221.

Hall, R. O., and J. L. Tank. 2003. Ecosystem metabolism controls nitrogen uptake in streams in Grand Teton National Park, Wyoming. Limnology and Oceanography 48:1120-1128.

Houser, J. N., P. J. Mulholland, and K. O. Maloney. 2005. Catchment disturbance and stream metabolism: patterns in ecosystem respiration and gross primary production along a gradient of upland soil and vegetation disturbance. Iournal of the North American Benthological Societv 24:538-552.

Ice, G. G., D. G. Neary, and P. W. Adams. 2004. Effects of wildfire on processes. Journal of Forestry 102:16-20.

Isaak, D., C. Luce, B. Rieman, D. Nagel, E. Peterson, D. Horan, S. Parkes, and G. Chandler. 2010. Effects of climate change and recent wildfires on stream temperature and thermal habitat for two salmonids in a mountain river network. Ecological Applications 20:1350-1371.

Koetsier, P., T. R. B. Krause, and Q. M. Tuckett. 2010. Present effects of past wildfires on leaf litter breakdown in stream ecosystems. Western North American Naturalist 70:164-174.

Koetsier, P., Q. Tuckett, and J. White. 2007. Present effects of past wildfires on the diets of stream fish. Western North American Naturalist 67:429-438.

Lamberti, G. A., S. V. Gregory, L. R. Ashkenas, R. C. Wildman, and K. M. S. Moore. 1991. Stream ecosystem recovery following a catastrophic debris flow. Canadian Journal of Fisheries and Aquatic Sciences 48:196-208.

Lamberti, G. A., and A. D. Steinman. 1997. A comparison of primary production in stream ecosystems. Iournal of the North American Benthological Society 16:95-103.

Lane, P. N. J., G. J. Sheridan, and P. J. Noske. 2006. Changes in sediment loads and discharge from small mountain catchments following wildfire in south eastern Australia. Iournal of Hydrology 331:495-510.

Lyon, J. P., and J. P. O'Connor. 2008. Smoke on the water: can riverine fish populations recover following a catastrophic fire-related sediment slug? Austral Ecology 33:794-806.

McGarigal, K., A. Cushman, and S. Stafford. 2000. Multivariate statistics for wildlife and ecology research. Springer-Verlag, New York.

Meyer, G. A., and J. L. Pierce. 2003. Climatic controls on fireinduced sediment pulses in Yellowstone National Park and central Idaho: a long-term perspective. Forest Ecology and Management 178:89-104.

Meyer, G. A., J. L. Pierce, S. H. Wood, and A. J. T. Jull. 2001. Fire, storms, and erosional events in the Idaho batholith. Hydrological Processes 15:3025-3038.

Mihuc, T. B., and G. W. Minshall. 1995. Trophic generalists vs. trophic specialists: implications for food web dynamics in post-fire streams. Ecology 76:2361-2372.

Minshall, G. W. 1978. Autotropy in stream ecosystems. BioScience 28:767-771

Minshall, G. W., J. T. Brock, D. A. Andrews, and C. T. Robinson. 2001. Water quality, substratum and biotic responses of five 
central Idaho (USA) streams during the first year following the Mortar Creek fire. International Journal of Wildland Fire 10:185-199.

Minshall, G. W., J. T. Brock, and J. D. Varley. 1989. Wildfires and Yellowstone stream ecosystems: a temporal perspective shows that aquatic recovery parallels. BioScience 39:707715.

Minshall, G. W., C. T. Robinson, and D. E. Lawrence. 1997. Postfire responses of lotic ecosystems in Yellowstone National Park, U.S.A. Canadian Journal of Fisheries and Aquatic Sciences 54:2509-2525.

Moody, J. A., and D. A. Martin. 2001. Initial hydrologic and geomorphic response following a wildfire in the Colorado front range. Earth Surface Processes and Landforms 26:1049-1070.

Mulholland, P. J., C. S. Fellows, J. L. Tank, N. B. Grimm, J. R. Webster, S. K. Hamilton, E. Martí, L. Ashkenas, W. B. Bowden, W. K. Dodds, W. H. McDowell, M. J. Paul, and B. J. Peterson. 2001. Inter-biome comparison of factors controlling stream metabolism. Freshwater Biology 46:1503-1517.

Naiman, R. J., J. M. Melillo, M. A. Lock, T. E. Ford, and S. R. Reice. 1987. Longitudinal patterns of ecosystem processes and community structure in a subarctic river continuum. Ecology 68:1139-1156.

Odum, H. T. 1957. Primary production measurements in eleven Florida springs and a marine turtle-grass community. Limnology and Oceanography 2:85-97.

Parise, M., and S. H. Cannon. 2012. Wildfire impacts on the processes that generate debris flows in burned watersheds. Natural Hazards 61:217-227.

Pettit, N. E., and R. J. Naiman. 2007. Fire in the riparian zone: characteristics and ecological consequences. Ecosystems 10: 673-687.

Pierce, J. L., G. A. Meyer, and A. J. T. Jull. 2004. Fire-induced erosion and millennial-scale climate change in northern ponderosa pine forests. Nature 432:87-90.

Reice, S. R. 1994. Nonequilibrium determinants of biological community structure. American Scientist 82:424-435.

Resh, V. H., A. V Brown, A. P. Covich, M. E. Gurtz, H. W. Li, G. W. Minshall, S. R. Reice, A. L. Sheldon, J. B. Wallace, and C. Robert. 1988. The role of disturbance in stream ecology. Iournal of the North American Benthological Society 7:433-455.

Roberts, B. J., P. J. Mulholland, and W. R. Hill. 2007. Multiple scales of temporal variability in ecosystem metabolism rates: results from 2 years of continuous monitoring in a forested headwater stream. Ecosystems 10:588-606.

Robinson, C. T., U. Uehlinger, and G. W. Minshall. 2005. Functional characteristics of wilderness streams twenty years following wildfire. Western North American Naturalist 65:1-10.

Rosenberger, A. E., J. B. Dunham, J. M. Buffington, and M. S. Wipfli. 2011. Persistent effects of wildfire and debris flows on the invertebrate prey base of rainbow trout in Idaho streams. Northwest Science 85:55-63.

Rosenberger, A. E., J. B. Dunham, and H. Neville. 2012. Fish life histories, wildfire, and resilience-a case study of Rainbow Trout in the Boise River, Idaho. Pages 187-194 in C. Luce, P. Morgan, K. Dwire, D. Isaak, Z. Holden, and B. Rieman (editors). Climate change, forests, fire, water, and fish: building resilient landscapes, streams, and managers. General Technical Report RMRS-GTR-290. US Forest Service, Rocky Mountain Researh Station, Fort Collins, Colorado.

Rulli, M. C., and R. Rosso. 2007. Hydrologic response of upland catchments to wildfires. Advances in Water Resources 30: 2072-2086.

Shakesby, R. A., and S. H. Doerr. 2006. Wildfire as a hydrological and geomorphological agent. Earth-Science Reviews 74: 269-307.

Spencer, C. N., K. O. Gabel, and F. R. Hauer. 2003. Wildfire effects on stream food webs and nutrient dynamics in Glacier National Park, USA. Forest Ecology and Management 178:141-153.

Sweeney, B. W., T. L. Bott, J. K. Jackson, L. A. Kaplan, J. D. Newbold, L. J. Standley, W. C. Hession, and R. J. Horwitz. 2004. Riparian deforestation, stream narrowing, and loss of stream ecosystem services. Proceedings of the National Academv of Sciences of the United States of America 101:1413214137.

Tsivoglou, E., and L. Neal. 1976. Tracer measurement of reaeration. III. Predicting the capacity of inland streams. Journal of the Water Pollution Control Federation 48:2669-2689.

Uehlinger, U. 2000. Resistance and resilience of ecosystem metabolism in a flood-prone river system. Freshwater Biology 45:319-332.

Uehlinger, U., B. Kawecka, and C. T. Robinson. 2003. Effects of experimental floods on periphyton and stream metabolism below a high dam in the Swiss Alps (River Spöl). Aquatic Sciences 65:199-209.

Vannote, R. L., G. W. Minshall, K. W. Cummins, J. R. Sedell, and C. E. Cushing. 1980. The river continuum concept. Canadian Journal of Fisheries and Aquatic Sciences 37:130-137.

Verkaik, I., M. Rieradevall, S. D. Cooper, J. M. Melack, T. L. Dudley, and N. Prat. 2013. Fire as a disturbance in Mediterranean climate streams. Hydrobiologia 719:353-382.

Westerling, A. L., H. G. Hidalgo, D. R. Cayan, and T. W. Swetnam. 2006. Warming and earlier spring increase western U.S. forest wildfire activity. Science 313:940-943.

Wolman, M. G. 1954. A method of sampling coarse river-bed material. American Geophysical Union Transactions 35:951956.

Young, R. G., and A. D. Huryn. 1999. Effects of land use on stream metabolism and organic matter turnover. Ecological Applications 9:1359-1376. 